University of Rhode Island

DigitalCommons@URI

Open Access Dissertations

1997

\title{
THE FATHER'S ROLE IN SELF-CONCEPT DEVELOPMENT
}

Jon Lopez Kimpton

University of Rhode Island

Follow this and additional works at: https://digitalcommons.uri.edu/oa_diss

\section{Recommended Citation}

Lopez Kimpton, Jon, "THE FATHER'S ROLE IN SELF-CONCEPT DEVELOPMENT" (1997). Open Access Dissertations. Paper 1093.

https://digitalcommons.uri.edu/oa_diss/1093

This Dissertation is brought to you for free and open access by DigitalCommons@URI. It has been accepted for inclusion in Open Access Dissertations by an authorized administrator of DigitalCommons@URI. For more information, please contact digitalcommons-group@uri.edu. 


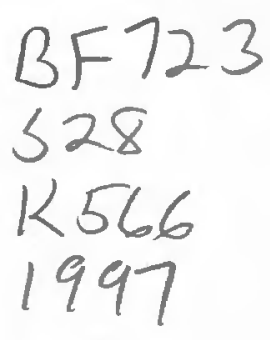

THE FATHER'S ROLE IN SELF-CONCEPT DEVELOPMENT

BY

JON LOPEZ KIMPTON

A DISSERTATION SUBMITTED IN PARTIAL FULFILLMENT OF THE REQUIREMENTS FOR THE DEGREE OF

DOCTOR OF PHILOSOPHY

IN

PSYCHOLOGY

39025221

UNIVERSITY OF RHODE ISLAND

1997 


\begin{abstract}
The present study was undertaken to provide information on the relationship between father involvement and multiple dimensions of a child's self-concept. The Father Involvement Scale (FIS), a measure of father involvement and substitute father involvement, was constructed for use in this research. Included in the study were 104 sixth and seventh grade middle school children (ages 11-14). Each were administered the Multidimensional Self-Concept Scale (Bracken, 1994). Scores from the FIS were used to divide the participants into four groups. Results from a MANOVA yielded a significant main effect for substitute father involvement, but not father involvement. Potential reasons for these findings are discussed. Psychometric properties of The FIS show initial promise, and potential applications for this scale are discussed.
\end{abstract}




\section{Acknowledgments}

This dissertation could not have been completed without the contribution of several people. First, I would like to thank the members of my dissertation committee, Drs. Henry Biller, Peter Merenda, Jerry Schaffran, Charlie Collyer, and Gwenneth Rae. I am very grateful for their caring commitment to my education as well as their enthusiasm to convey their expertise and knowledge. Dr. Rae, the chair of my committee, was especially helpful in examining the practical implications of this research, and I thank her for her thoughtful recommendations. Dr. Collyer was instrumental in identifying central methodological issues, and offered important suggestions in clarifying procedural characteristics of this research.

A special thanks goes to my major professor, Dr. Henry Biller. He is truly a master within the fields of child development and parenting, and I am indebted to his patience and pedagogy throughout my graduate education. Equally important to me was his friendship and encouragement during times when I was particularly frustrated with the progress of this project. At each setback that I experienced, he gave me the stamina to continue.

I am also especially grateful to Dr. Peter Merenda, who, even in retirement, continues to demonstrate his fervent desire to participate in the education and development of graduate students. He has devoted his career to the improvement of psychology as a science, and even after these years of his instruction, I am still in awe of 
his knowledge of statistics and methodology. The skills he has taught me will be of infinite assistance and utility throughout my career.

I would also like to thank Dr. Jerry Schaffran for his patience and thoughtful guidance throughout this dissertation. His suggestions at each stage of this project, through earliest formulation to final presentation, were of enourmous assistance. His foresight and concern allowed me to anticipate potential difficulties and procedural problems, and helped me to carry out this research as smoothly as possible.

I feel confident in stating that this research would never have taken place were it not for the efforts of Ms. Pamela Ardizzone. She was instrumental in obtaining the subject sample and coordinating the practical and procedural elements of this study. Also, her boundless energy and humanitarianism in educating and advocating for underpriveleged children is an inspiration.

I would also like to express my appreciation for all the parents and children who participated in this research project. They volunteered their time and consideration to make this study a reality. Their participation in this research demonstrates their genuine desire to make a contribution to the betterment of children's lives.

Many others provided important advice and contributed a great deal to this research, as well as my professional development. Dr. Denise DeZolt provided excellent recommendations on the regulations and concerns regarding research with minors. Her efforts in the early stages of this research allowed the project to receive approval in an expeditious manner. Dr. Ann Varna Garis helped me to evaluate various aspects of the project and the problems I faced along the way. In addition, she has been instrumental in 
my clinical education, demonstrating and teaching practical and effective models to increase the functioning of families and other systems. I must also express my appreciation to Dr. Larry Grebstein for his guidance and support during especially difficult moments of my graduate training. In addition, I thank him for modeling a career combining excellence in teaching with outstanding clinical service; I aspire to meet his example.

Finally, my greatest appreciation goes to my family. Graduate school was difficult, and without their support I may have chosen not to persevere. My wife, Anne, has been incredibly supportive and encouraging throughout graduate school, at times doing all the work for our marriage to be successful. Thank you for your love and understanding, and putting up with me when I did not do my share of the work. You are by far, the most important part of my life, and I am truly blessed to experience our relationship and the love we share. My heartfelt appreciation also goes to my mother, Rosemary Lopez Kimpton, who, through her own example, has instilled in me a strong sense of empathy and determination to help others. Thank you for your love and support, and for all the years of sacrifice so that I may have this opportunity. I must also express my deepest gratitude to my father, Michael Turano, for providing me with a model of a father-son relationship, and demonstrating the tremendous impact that paternal love has on a child's life. In many ways, this dissertation is dedicated to you. 
Introduction 1

Paternal importance in child development 1

Paternal influence on self-concept and self-esteem in children $\quad 3$

Self-concept vs. self-esteem $\quad 4$

Major theories of self-esteem and self-concept 5

$\begin{array}{ll}\text { Self-esteem research } & 7\end{array}$

Measures of self-concept and self-esteem 9

Coopersmith Self-Esteem Inventory 9

Piers-Harris Children's Self-Concept Scale $\quad 10$

Harter Self-perception Profile $\quad 10$

The Multidimensional Self Concept Scale $\quad 12$

Potential contribution to the field 14

$\begin{array}{ll}\text { Method } & 16\end{array}$

$\begin{array}{ll}\text { Subjects } & 16\end{array}$

$\begin{array}{ll}\text { Measures } & 17\end{array}$

Paternal Involvement $\quad 17$

$\begin{array}{ll}\text { Self-Concept } & 18\end{array}$

$\begin{array}{ll}\text { Procedure } & 18\end{array}$

Results $\quad 20$

Parent Involvement Scale $\quad 20$

Father Involvement Scale $\quad 21$

Substitute Father Involvement Scale 22

Multidimensional Self-Concept Scale

MANOVA 23

Predictions and hypotheses $\quad 26$

Discussion $\quad 28$

Tables $\quad 38$

Appendix A $\quad 46$

Appendix B $\quad 48$

Appendix C $\quad 50$

Bibliography $\quad 54$ 
List of Tables

Table 1 38

Eigenvalues for each item on parent involvement scale

Table 2

Component loadings and communality

Table 3

Component loadings for father and substitute father involvement scale and communality

Table 4 41

Internal consistency coefficients for the six subscales and total scale for MSCS

Table 5

Univariate F-tests with $(1,95)$ df for Father Involvement

Table 6

Cell Means for each group on self-concept domains

Table 7 44

Interaction effect between father involvement and substitute father involvement on six aspects of self-concept

Table 8 45

Univariate F-tests for Substitute father involvement with $(1,95) \mathrm{df}$ 


\section{Introduction}

There is much agreement that self-concept is central to the individual's psychological well being. However, the development of self-concept is not as clear. Although much work has been done in this field, one area of research remains virtually untouched: the role of the father in the development of self-concept in children. Therefore, the present study was undertaken to further investigate this relationship. Of particular interest are the effects of the level of father involvement on the child's self-perceptions. Also, in situations in which a child's father is absent or is not very involved, would the availability of a substitute father figure (uncle, teacher, coach, etc.) make a difference in how this particular child perceives him or herself?

\section{Paternal importance in child development}

A vast amount of research has been devoted to the mother's role in the development of self-concept. In contrast, there have been very few attempts to investigate the father's role in the development of self-concept. This is not surprising given the socio-political nature of western society since the industrial revolution. Since then, in most cases, it has been the mother who has been expected to be the primary caregiver for children, while the father works outside the home. In the role of child caregiver and nurturer, the father has, at best, come to be seen as second-rate and at worst, incompetent.

There exists a substantial amount of evidence, however, that fathers do play a crucial role in their children's development. For example, Blanchard and Biller (1971) found that fathers play a major role in the development of their child's cognitive 
functioning. Their results revealed that boys whose fathers were highly available scored significantly higher on achievement tests and achieved better grades.

Fathers also play a critical role in sex role development. Goodenough (1957) found that fathers influence their children's sex role development more than do mothers. With their sons, they offer a male role model; someone to whom the children can look to model appropriate sex role behavior. Biller $(1974$, p. 15$)$ writes: "If a boy is to develop a positive masculine self-concept, he must receive consistent nurturance and positive feedback [from a significant older male]. Contrary to the supposition of most identification theorists, even in the first year or two of life, many children develop firm attachments to their fathers." Daughters are influenced by how the father differentiates between his masculine and her feminine role and what types of behavior he considers appropriate for each (Biller, 1974). When the father is present in the home, he provides the first male interactions for his daughter, and offers a foundation for ways to act and behave in future relationships with males.

The father can also be a role model for his child's moral development and impulse control. Hoffman (1971) found that seventh grade father-absent boys scored lower than their father-present counterparts in measures of internal moral judgment, guilt following transgressions, acceptance of blame, moral values, and role conformity. Biller (1974, p. 66) describes how father absence can affect his son: "The father-absent boy often lacks a model from whom to learn to delay gratification and to control his aggressive and destructive impulses. A boy who has experienced paternal deprivation may have particular difficulty in respecting and communicating with adult males in position of authority." 


\section{Paternal influence on self-concept and self-esteem in children}

There is additional evidence that fathers influence their children's self-concept and personality adjustment. Rosenberg's (1965) findings suggest that early fathering has a profound impact. His results showed that children who experience early father absence were not as well adjusted as their father-present counterparts. He also discovered that adolescents who have closer relationships with their fathers are higher in self-esteem than those with more detached relationships with their fathers. Coopersmith (1967) found that elementary aged boys who had high self-esteem could confide in their fathers. Reuter and Biller (1973) studied college males' personality adjustment as it related to their perception of their father's nurturance and availability. They found that college males who experienced at least moderate paternal nurturance combined with at least moderate paternal availability, scored higher on the personality adjustment measures. In contrast, college males who experienced either low paternal nurturance or low paternal availability or both, scored lower on the personality adjustment measures. Interestingly, Biller (1973, p. 56) reports that those college males who revealed that their fathers were available much of the time but gave them little attention seemed to be especially handicapped in their psychological functioning... the boy with an unnurturant father may be better off if his father is not very available. This is consistent with evidence that suggests that fatherabsent boys often have better personality adjustments than boys with passive ineffectual fathers (Biller, 1971, 1972)." 
Amato (1986) conducted a study to investigate the influence of the father-child relationship on the child's self-concept. He found that the father-child relationship was equally if not more influential than the mother-child relationship. Amato studied both primary school children and adolescents. He administered the Piers-Harris self-concept scale and asked each subject the following four questions: 1. Does your father (mother) talk to you much? 2. Is your father(mother)interested in the things you do? 3. Do you think your father(mother) spends enough time with you? 4. Do you wish your father (mother) would help you more? Amato studied children from three types of families: intact, stepfather, and non-custodial father. He found that in both intact and stepfather families, the father figure had as much influence on self-concept as the mother. Noncustodial fathers did not have much influence on their child's self-concept (Amato, 1986).

\section{Self-Concept vs. Self-Esteem}

Although self-concept and self-esteem are two distinctly different constructs, many authors have used the terms interchangeably. This has resulted in much confusion both among lay people and professionals. Self-Concept is defined as an individual's selfconstruct or the makeup of characteristics that is the self. In contrast, self-esteem, as defined in the Encyclopedia of Psychology (Corsini, 1984) is the hypothetical overall or global level of self-evaluation or self-regard. Self-Esteem, then, is actually the evaluative component that the self places on the self-construct, and is thus subsumed under selfconcept.

The confusion between the two constructs and their terminology poses a problem when discussing the relevant literature, both past and present. When the terms self- 
concept and self-esteem are mentioned throughout this study, the reader should refer to the aforementioned definitions. Contributing to this quandary are some of the most prevalent measures currently in use. Indeed, several items on the Multidimensional SelfConcept Scale (the instrument used for this study) could be considered evaluative, or better measures of self-esteem than self-concept. However, the Multidimensional SelfConcept Scale possesses the best psychometric properties of all scales available for use with the subject population employed in this research.

Major theories of self-esteem and self-concept

Self-Concept and self-esteem have been conceptualized in various ways by different theorists. James (1890) believed that global self-esteem represented the ratio of an individual's personal successes to his or her pretensions. According to James' theory, the individual who attained success in areas which s/he felt were important, would develop high self-esteem. Conversely, if an individual experiences failures in areas in which s/he deems important, the individual will develop low self-esteem.

Cooley (1909) believed that the major predictor of self-concept is the amount of positive regard the individual has experienced from significant others in his/her life.

Cooley explained that the self actually represents the reflected appraisals of significant others. Thus, each of us incorporates the attitudes and perceptions, whether positive or negative, that we believe others hold toward us. The extent that these attitudes affect us is determined by the importance of the person from which the attitude comes.

G.H. Mead followed up on Cooley's theory of self-concept. However, it seems he had also written more on the evaluative, self-esteem portion of self-conceptions. He 
believed that self-concept is largely derived from the reflected appraisal of others. The gauge of self-evaluation is a mirror image of the criteria employed by the important persons of our social world. As children we internalize these criteria, observe how we are regarded, and value ourselves accordingly..."if he places high value upon himself, there have been persons in his life who have treated him with concern and respect; if he holds himself lowly, significant others have treated him as an inferior object." (Mead, 1934)

Prescott Lecky postulated that self-concept is an integral part of an individual's personality formation and, until late adolescence or early adulthood, is still quite malleable. According to Lecky, all individuals possess an inner core, or basic self-concept, which can be described as a central identity. From the earliest childhood years to adulthood, the individual experiences events in his/her environment which are either consistent or inconsistent with their basic self-concept. Thus, throughout the child's development, he is in the process of assimilating or rejecting new ideas depending on the degree of congruity between this new experience and the basic self-concept.

Lecky also believed that different people were most important at various periods of the child's development. During the period of early childhood, the mother and father are the most constant factors, and thus have the greatest impact on the child. As the child matures, close friends and relatives become important. In late adolescence or early adulthood the individual meets his or her future mate who is then incorporated into this system first at the level of acquaintance and eventually replacing the parents as the most influential and constant factor impacting on the basic self-concept. By this time however, the basic self-concept is firmly established; the network of ideas and experiences consistent 
with the core are more stable and fixed. Therefore, it makes sense that in order to effect change to the basic self-concept, the individual must undergo some catastrophic event, or deeply meaningful experience or relationship.

Several clinicians have incorporated self-concept into their theories of psychological functioning. Harry Stack Sullivan agreed with Mead's theory of the development of self-concept (we regard ourselves as we believe others regard us) but elaborates more on the evaluative aspect of self-esteem. He goes on to say that "if we find an individual low in self-esteem, we assume that derogation by significant others has occurred in the previous life history of that individual and that he anticipates or perceives derogation in his present circumstances." Sullivan also emphasized the importance of the ability to thwart or diminish threats to self-esteem. He indicates that these coping strategies develop from the child's early interpersonal processes within the family.

Alfred Adler (1927) placed great importance on actual physical weaknesses as resulting in low self-esteem. However, Adler further explained how these physical deficiencies could prove to be motivating factors. He proposed that with acceptance, support, and encouragement of the parents and friends, children with inferiorities can compensate for these weaknesses and turn them into strengths.

\section{Self-esteem research}

Coopersmith (1967) conducted a landmark study to determine the important factors of high or low self-esteem. He studied 85 fifth grade children and inquired about their various experiences and how these experiences may be related to their various levels of self-esteem. Information about these experiences was obtained from the following 
three sources: 1) an eighty item questionnaire completed by the mother inquiring about parental attitudes and practices regarding childrearing; 2) an interview with the mother; and 3) an interview with the child inquiring about his/her perception of parental attitudes and practices. Additionally, a Thematic Apperception Test (TAT) was administered to each child to determine any unconscious perceptions toward their parents' child rearing practices. As was characteristic of the period before the 1970s, Coopersmith did not directly include the father in his study. However, he mentions that information about the father was obtained indirectly through the mother and the child.

Coopersmith found an association between certain childrearing conditions and the development of a healthy level of self-esteem in children. The first of these is total or nearly total acceptance of children by the father and mother. The second is that both the father and mother consistently and clearly defined limits for their children. The third is that within those limits, they allowed much latitude for individual behavior and expression.

Rosenberg's (1965) findings suggest that the closer, more intimate environment provided by the family has a greater relationship with self-esteem than does the broader social context. First, Rosenberg found that social class is only weakly related to selfesteem. Individuals in the upper and middle socio-economic classes were slightly more likely to report high self-esteem than individuals in the lower socio-economic class. These differences, however, were not as large or as regular as might have been expected. Also, although individuals in the lower class were more likely to report low self-esteem, there were just as many individuals in this group who reported high self-esteem. 


\section{Measures of Self-Concept and Self-Esteem}

Coopersmith Self-Esteem Inventory

The Coopersmith Self-Esteem Inventory has been one of the most widely used instruments to determine levels of self-esteem. It is a 50 item, unidimensional measure of self-esteem for use with children aged eight to fifteen. The inventory was developed by Coopersmith as an adaptation to the Rogers and Dymond (1954) scale. Coopersmith reworded several of the items and added many original ones as well. Coopersmith's final inventory consisted of items involving self-attitudes in the areas of peers, parents, school, and personal interests. This final inventory was administered to two fifth and sixth grade classes in Connecticut. The scores ranged from 40 to 100 , with a mean of 82.3 and standard deviation of 11.6. The inventory was then administered to 1,748 children attending public school in Connecticut. Fifty-six of these children were retested three years later. Test-retest reliability after this three year period was .70 .

The current manual for the Coopersmith Self-Esteem Inventory contains normative data from eight different samples. However, there is a cautionary statement warning test administers to develop local norms. One of the largest norming projects was performed by Kimball (1972). His study included 8,000 children from northern Mlinois. While the manual reports internal consistency coefficients ranging from .80 to .92 , Kimball reports internal consistency coefficients of .87 . to .92 . 


\section{Piers-Harris Children's Self-Concept Scale}

The Piers-Harris Children's Self-Concept Scale is another widely used instrument for investigating levels of self-concept in children. Six aspects of self-concept are assessed. These are anxiety, behavior, happiness and satisfaction, intellectual and school status, physical appearance and attributes, and popularity. The Piers-Harris was originally normed on a sample of 1,183 Pennsylvanian public school children in 1966 . The manual reports on many normative samples that have been studied since then. Internal consistencies for the Piers-Harris range from .88 to .92 . Test-retest reliabilities ranged from .42 to .96 (median $=.75$ ). The retest intervals for the 19 studies ranged from 14 days to one year.

\section{Harter Self-perception Profile}

The Harter Self-Perception Profile for Children (Harter, 1985) is a multidimensional instrument which attempts to tap perceived competence or adequacy in six specific domains. These domains are: scholastic competence; social acceptance; athletic competence; physical appearance; and behavioral conduct. In addition, The Self-Perception Profile assesses global self-worth. Each sub-scale provides a separate score, thereby allowing one to examine a profile of the child's evaluative judgments across domains. By providing separate measures of perceived competence in different domains, as well as an independent assessment of one's global self-worth, one can get a richer, and more diverse profile of an individual's self-concept than with a unidimensional assessment of self-concept that sums up scores from different domains to obtain a global score. A 
procedure which merely sums across domain-specific items (e.g. The Coopersmith SelfEsteem Inventory) will not uncover differences in an individual's perception of his or her competence in various aspects of life (Harter, 1985). Harter notes that the global selfconcept score on the Self-Perception Profile should not be considered a measure of general competence. However, this score can be useful in examining the relationship between global self-concept and the perceived competency score for the specific domains. Harter performed a norming project with four samples of children: 1) sixth and seventh grade; 2) sixth, seventh, and eighth grade; 3) third, fourth, fifth, and sixth grade; and 4) third, fourth, and fifth grade. Ninety percent of the subjects were caucasian children from lower middle to upper middle class families in Colorado. Sub-scale reliabilities for the four samples ranged from .71 to .86 , showing moderate to good reliability for the six sub-scales and global self-worth scale. Harter reports that means for these samples fluctuated around 3.0. Standard deviations were reported as ranging from .50 to .85 , indicating considerable variation among individuals.

Harter found differences related to both gender and grade level for certain subscales. In all samples boys saw themselves as more athletically competent, whereas girls saw themselves as better behaved than boys. In two middle school samples, boys saw themselves as more physically appealing than the girls saw themselves. Also, boys seemed higher in global self-worth than girls. Grade effects were found for the two middle school samples only. In one sample the sixth graders had significantly higher scholastic competence scores than the seventh graders. Similarly, scholastic competence decreased 
with grade level in a sample of sixth, seventh, and eighth graders. Scores on global selfworth also showed decreases according to grade level.

In order to determine if each domain was, in fact, a separate factor, factor analysis was utilized. An oblique rotation was performed on three of the samples, because the factors were intercorrelated. Factor loadings are reported as being substantial. There were no cross loadings greater than .18 , and the range of average cross loadings across the factors was between .04 and .08 (Harter, 1985).

\section{The Multidimensional Self Concept Scale}

The MSCS is, as the name implies, a multidimensional instrument which attempts to tap self-concept in six specific domains. These domains are: social, competence, affect, academic, family, and physical. The MSCS postulates a hierarchical model of selfconcept. Additionally, the six domains are thought to be moderately intercorrelated, each contributing to the central domain, global self-concept (Bracken, 1992). The MSCS was standardized on a sample of 2,501 children in grades 5-12. The sample included all major regions of the United States, thus providing an improvement over samples used for other widely used self-concept scales such as the Piers-Harris Children's Self-Concept Scale (Piers, 1984), the Self-Description Questionnaire (Marsh, 1990), the Tennessee SelfConcept Scale (Fitts, 1964), and the Harter Self-Perception Profile (1985).

Bracken (1992) found internal consistencies for the MSCS Total Scale to be .97 or higher. Total sample internal consistencies for six of the domain scales exceeded the .90 criterion. The exception was the competence scale with a total sample alpha coefficient of .87. 
Test-retest reliability data were collected for the MSCS. The MSCS was administered to 37 eighth graders. The time between the two testings was four weeks. Results revealed moderate test-retest correlations in the mid-.70s and above. The testretest correlation for the Total Scale was .90 .

Construct validity was suggested through principal factor analysis. Bracken (1992) notes that, "the difficulty in determining the underlying structure of a construct such as self-concept, is that typically factor analytic studies investigate only the structure of a single instrument. Because of the limited amount of marker variables, factor analysis will usually yield fewer factors than the number of domains being investigated." (p. 3) Bracken cites Woodcock (1990) as an example of a solution to this problem. Woodcock examined the construct of intelligence by including in the factor analysis several scales which purported to measure intelligence. Thus, the other measures acted as marker variables for studying the underlying construct of the measure of interest.

Bracken (1992) followed this example. He included four self-concept measures along with the MSCS in a principal factor analysis with varimax rotation. These scales included the Coopersmith Self-Esteem Inventory (Coopersmith, 1984), the Piers-Harris Children's Self-Concept Scale (Piers, 1984), the Self-Concept Index (Brown and Alexander, 1990), and the Tennessee Self-Concept Scale, Revised (Roid and Fitts, 1988). Each of the comparison measures possessed at least two defined subscales included in Bracken's (1990) proposed six domain construct of self-concept. Results of the factor analysis revealed that five of the six MSCS domains obtained the highest significant loadings (ranging from .55 on Affect to .81 on Family) on their respective factors. The 
competence scale proved to be the exception with only a .29 loading on the competence factor. Because of this finding, as well as others, both Bracken (1992) and Willis (1994) advise against the independent interpretation of the competence scale.

In addition, Bracken demonstrated convergent and divergent validity by correlating scores on the MSCS with scores on the Assessment of Interpersonal Relations, Coopersmith Self-Esteem Inventory, Piers-Harris Self-Concept Scale, and SelfDescription Questionnaire. Correlations between the MSCS and the comparison measures ranged from .69 to .85 . Divergent validity for the theoretically dissimilar sub-scales ranged from .02 (between the MSCS Family Scale and the SDQ Opposite Sex Relations Scale) to .77 (between the MSCS Competence Scale and the Piers-Harris Anxiety Scale) (Willis, 1994).

Because of its superior psychometric properties and the ability to assess several different areas of self-concept, the MSCS was chosen for use in this study. However, the MSCS is not without it problems. For example, only thirty-seven individuals were used to test reliability and this test-retest reliability study incorporated only a four week interval. Such a short interval would seem adequate if one were measuring the state of an event, but not a trait, such as self-concept, which is thought to be relatively stable at the ages for which the MSCS was intended.

\section{Potential Contribution to the field}

Although there is evidence for the relationship between father involvement and positive child development, only the Amato (1986) study has directly investigated the variables of father involvement and global self-concept. Amato used the Piers-Harris Self- 
Concept Scale, a unidimensional assessment device. This study intends to employ the Multidimensional Self Concept Scale (MSCS) (Bracken, 1992). By providing separate measures of self-concept in different domains, this scale provides a richer, and more diverse profile of an individual's self-concept than is possible from a unidimensional assessment of self-concept which simply sums up scores from different domains to obtain a global score. A procedure which merely sums across domain-specific items (e.g. The Coopersmith Self-Concept Inventory) will not uncover differences in an individual's perception of his or her competence in various aspects of life (Harter, 1985). Therefore, the present study seeks to produce a more detailed and accurate picture of the relationship between father involvement and several different areas of self-concept.

In addition, it is hoped that this study will yield clues as to how children with low father involvement or father absence can be helped to overcome self-concept deficiencies. All too many children grow up having limited or no contact with their fathers. It is hoped that the results of this study can be utilized by school and clinical psychologists, guidance counselors, teachers, social workers, parent-teacher associations, community leaders, and others interested in the welfare of children and families, to provide effective interventions to prevent deficiencies or potential damages to the self-concept of children at particular risk.

The nurturant and available father is the most important male in his child's life. The care and love that he expresses informs his child that he or she is valued. Because of the importance of the father in the child's life, he has a profound influence on the development of the child's self-concept. Therefore, it is predicted that, in the current 
study, those children who are exposed to high levels of father involvement will score higher on measures of self-concept than children with low father involvement or no father involvement. Also, to the extent that self-concept is related to the child being valued by a significant adult male figure, it is predicted that children who have experienced low father involvement but are fortunate enough to experience substitute father involvement (uncle, grandfather, coach, etc.) will score higher on self-concept measures than those father absent children who do not have another significant male role model in their lives.

A father's influence may vary in different areas of a child's self-concept (athletic, scholastic, social, etc.). However, because to date there has been no research investigating the relationship between father involvement and specific areas of self-concept, the degree of correlation between these relationships are not known. Therefore, it is this author's intention to investigate the hypothesis that father involvement will have a differential effect on the six areas of self-concept measured by the MSCS.

\section{Method}

\section{Subjects}

The participants consisted of sixth and seventh grade students. This sample was chosen for several reasons. First, children at this age should have no problems understanding the question format on the MSCS. They are at a developmental age at which trait labels (e.g., popular, smart, good-looking) are meaningful. They should, by this age, have a concept of their global self-worth as a person (Harter, 1985).

The study included sixth and seventh grade children from a middle school in a rural section of Rhode Island. The study was conducted in this school because the 
administrators in this school agreed to participate whereas others did not. Therefore, this sample was not chosen randomly, but rather for purposes of convenience. The ethnic makeup of this school is predominantly White. However, the school district has a strong Italian and Irish influence, and rapidly growing African-American and Latino populations. Other ethnic groups represented include Asian and Portuguese. Residents of this school district are described as representative of the whole range of socioeconomic classes. Although the school district is predominantly White, every attempt was made to include ethnic minority children in the sample. Also, an attempt was made to include both girls and boys in the sample.

\section{Measures}

\section{Paternal Involvement}

A survey measuring demographic characteristics, paternal involvement and involvement of substitute paternal figures was administered. This survey was constructed by using portions of the Paternal Involvement in Child Care Index (Radin, 1985), a questionnaire developed by Blanchard and Biller (1971), and other items added by this author. The purpose of this survey was to assess paternal involvement, and substitute paternal involvement with the child in various activities. In addition, an assessment was made of family demographics (number of brothers and sisters, presence of mother, father, and other adults in home) and father absence (when father became absent).

Data from this Parent Involvement Scale were submitted to a principal component analysis to determine if questions were, in fact, measuring the constructs of father involvement, and substitute father involvement. While other methods of factor analysis 
were available for use (common factor analysis and confirmatory factor analysis), principal component analysis was chosen because of the exploratory nature of the project. The purpose of the procedure was to analyze a pool of items in the development of the Parent Involvement Scale. The principal component analysis of this survey revealed three distinct factors (paternal involvement, substitute paternal involvement, and family demographics). Self-Concept

The Multidimensional Self Concept Scale was used for this study. A complete description of the MSCS including psychometric properties is given above.

\section{Procedure}

The middle school principal and district superintendent of schools were contacted and informed of the research study. Each agreed to participate and granted permission for the study to take place. Envelopes containing descriptions of the study, parent questionnaires, and consent forms were mailed to the parents of the sixth and seventh grade students with instructions to read the consent form and if they agreed to participate, sign the consent form, fill out the parent survey, and mail these materials back to the author in the enclosed stamped envelope. Those children whose parents consented to have them participate were given a child assent form to read and sign if they chose to participate.

Those children who agreed to participate and whose parents gave consent completed the MSCS in a group format in their classrooms. Those children whose parents did not grant permission for their involvement or who personally refused to participate in the study were given written exercises to work on while the administration of the MSCS was taking place. Both activities (the MSCS and written exercises) took approximately 
30 minutes to complete. The children were informed that they did not have to participate and that they may quit at any time.

One hundred and six participants were included in the final analysis. These participants were included because completed parent involvement scales were returned, parental consent and child assent were given. Of these 106 participants, five were not administered the multidimensional self-concept scale (two refused to be tested, and three were unavailable on each of the five testing dates). After participant attrition, 101 participants were included in the analyses.

Participants were assigned to one of four groups according to the scores that their parents obtained on the father involvement and substitute father involvement scales. These scores were converted to t-scores. Parental data for both the father involvement and substitute father involvement scales were relatively normal with acceptable levels of kurtosis and skewness. The groups were separated at the fiftieth percentile of scores on the father involvement scale and the substitute father involvement scale. These groups were: 1) high father involvement with high substitute father involvement $(\mathrm{n}=28), 2)$ high father involvement with low substitute father involvement $(\mathrm{n}=26), 3)$ low father involvement with high substitute father involvement $(n=29)$, and 4) low father involvement with low substitute father involvement $(n=18)$.

The data were subjected to a multivariate analysis of variance (MANOVA). The independent variables were level of father involvement and level of substitute father involvement. The six subscales on the MSCS were the dependent variables. The decision 
to use the MANOVA procedure was made over the use of multiple ANOVAs because the dependent variables, aspects of self-concept, were thought to be related to each other.

\section{Results}

\section{$\underline{\text { Parent Involvement Scale }}$}

A principal component analysis was conducted on the Parent Involvement Scale. Varimax rotation was used because it was not known whether or not the maternal, paternal, and substitute involvement variables would be related. Because orthogonal rotation treats the underlying processes as independent this type of rotation has been said to "strain reality."(Tabachnik and Fidell, 1989) However, because the independence of each component was unknown, and because of the relative ease over oblique rotation in interpreting, describing, and reporting results, varimax rotation was chosen.

With a data set that inchudes several variables that clearly define separate factors and few variables that load highly on more than one factor, results would be expected to be similar with both orthogonal and oblique rotations. When an oblique rotation was conducted the variable loadings were very similar. All variables remained on the factors proposed in the varimax rotation.

Velicer's minimum average partial (MAP) method (Velicer, 1976) was used to determine how many components to retain. The MAP procedure is considered to be one of if not the most accurate method for retaining components. In a comparison of different techniques, Zwick and Velicer (1986) found that the MAP procedure was more often accurate and less variable than the K1, Bartlett, or scree methods. When they found the 
MAP method to be in error, it tended to underestimate the number of components to be retained.

In the present study the MAP procedure indicated that three components should be retained. The first component, father involvement, accounted for $26 \%$ of the total variance. The second component, mother involvement, accounted for $12 \%$ of the total variance. The third component corresponded to combined substitute father and mother involvement. This component accounted for $13 \%$ of the total variance. Taken together, the three components accounted for $51 \%$ of the total variance. Also, the eigenvalues for each item on the Paternal Involvement Scale decrease in order with no negative values.

\section{Insert table 1 here}

The structure of these components appears to be very good. All items loading on a component are above .40 with most in the .60 to .80 range. Factor intercorrelations ranged from -.12 to .27 , indicating that the components were not very related. Only one item (item 4 - percentage of time mother is primary caregiver) loaded on two components. This item's loading on component one was .60 and on component two, .44. Because of this item's complex loading it was not included in the final scale. Another item (item nine - mother's availability in evenings) did not load above .40 on any of the three components. Therefore, it was also discarded for the final scale.

Insert table 2 here

\section{Father Involvement Scale}

An analysis of internal consistency of the Father Involvement Scale yielded a standardized alpha of .93. After reviewing the variability of each of the 11 items on the 
father involvement scale, it was decided to discard three items (Father presence at home in afternoons, Father presence at breakfast, and Percentage of time father was the primary caregiver). Without these items, internal consistency was increased for items on the Father Involvement Scale (alpha $=.93)$, indicating that the items on this subscale were homogeneous in their contribution to the father involvement component. The final Father Involvement Scale included eight items: 1) Father involvement in care for children, 2) Decision when child should be disciplined, 3) Decision when child can try new things, 4) Father presence on weekends, 5) Father presence in evenings, 6) Average number of hours spent with father on typical day, 7) Number of hours spent with father on weekends and during summer, 8) Frequency of outings with father.

\section{Substitute Father Involvement Scale}

Three items were included on the substitute father involvement scale. The three items were: 1) number of hours spent with other men on an average day; 2) time spent with other men on weekends and in the summer; 3) frequency of outings with other men. The internal consistency coefficient of these items was .80.

A principal component analysis was conducted using only the father involvement and substitute father involvement questions. The first component, father involvement accounted for $45.5 \%$ of the total variance. The second component, substitute father involvement, accounted for $17 \%$ of the total variance. Together these two components accounted for $62.5 \%$ of the total variance. 


\section{Multidimensional Self-Concept Scale}

Internal consistencies for each of the six subscales, as well as total scale, were quite good. Most of the standardized alphas for the MSCS were in the .90 range with only one, Competency, falling below $.90(.88)$. It is interesting to note that, as mentioned above in the discussion of psychometric properties of the MSCS, Bracken (1992) found that the component for Competency had relatively inadequate factor structure. The reader is reminded that both Bracken (1992) and Willis (1994) in his review of the MSCS caution against interpretability of the Competence subscale. The current findings seem to provide further evidence of this component's relative weakness compared to the other five components.

Insert table 4 here

\section{MANOVA}

The number of participants in the four cells of the MANOVA ranged from 18 to 29. Unequal cell sizes cause a problem in a MANOVA because the factorial design is no longer orthogonal. Hypotheses about main effects and interactions are no longer independent, and sums of squares are not additive. The various sources of variability contain overlapping variance and the same variance can be attributed to more than one source. If effects are tested without taking the overlap into account, the probability of a Type I error increases because systematic variance contributes to more than one test (Tabachnick and Fidell, 1989). 
A number of strategies are available to help with this problem. The simplest strategy is to randomly delete cases from each of the cells with the greater number of participants until all the $n s$ in each cell are equal. In the present study the smallest $\mathbf{n}$ was 18. Therefore, this strategy was rejected due to concern that decreasing all cell sizes to 18 would decrease the internal validity of the study.

When deciding on which procedure is optimal, one must also consider the type of research being conducted, experimental or non-experimental. The present study is nonexperimental because participants were not randomly selected or randomly distributed to each variable and no manipulation of variables was performed. Therefore, the differences in sample size may reflect true differences in the population. To artificially equalize the ns would distort these differences and decrease generalizability, or external validity.

The SPSSx software package offers two types of adjustments for MANOVA. The sequential approach is generally used in non-experimental research in which sample sizes reflect the importance of cells. This approach allows the researcher to set up the hierarchy for adjustment of main effects and interactions.

The other type of adjustment offered by SPSSx is called the unique approach. In this approach, each main effect and interaction is assessed after adjustment is made for all other main effects and interactions. Because of discrepancies in the same method using different software programs, and disagreements as to the best adjustment method in a research situation, some researchers advocate use of the unique approach in all cases (Tabachnik and Fidell, 1989). However, with a non-experimental design, there is a risk of losing power and interpretability. 
Both types of adjustments were conducted separately on the MANOVA. The unique approach did provide more conservative results than the sequential approach. However, the small differences in results yielded from the two adjustments made no impact on the statistical significance of any MANOVA main effects or interaction effect.

The discrepancy between sample sizes increased the possibility that the assumption of homogeneity of variance would be violated. Additionally, Tabachnik and Fidell (1989) state that when there exists a large difference in cell sizes, "the $\mathrm{F}$ test is too liberal, leading to increased Type I error rate and an inflated alpha level. An examination of the standard deviations for each cell revealed that in only one aspect of self-concept, family, did the smallest group, low father involvement with low substitute father involvement, have the largest variance.

To test whether or not the assumption of homogeneity of variance had been violated at the multivariate level a Box's $\mathbf{M}$ test for homogeneity of dispersion matrices was conducted. Box's $M$ test has been said to be a very sensitive test (Tabachnik and Fidell, 1989). The results of this test revealed that the assumption of homogeneity of variance had indeed been violated. To determine where this assumption was being violated, a Bartlett-Box univariate homogeneity of variance test was performed on each self-concept variable. The only violation of homogeneity of variance occurred in the family variable. Both log and square root transformations of the Family variable were attempted, but these made no difference in the violation of the assumption for this variable. 
Although the assumption of homogeneity of variation was violated, the degree of this violation was not severe. To determine the impact of this violation, two separate MANOVAs were conducted, one with the family self-concept included in the analysis, the other without. The results for each variable did not change in terms of statistical significance.

\section{Predictions and Hypotheses}

The following hypotheses and predictions were posed above:

Hypothesis 1: Because a father's influence may vary in different areas of a child's selfconcept (physical, academic, social, etc.), it was hypothesized that father involvement produces a differential effect on the six areas of self-concept measured by the MSCS.

Prediction 1: It was predicted that the group of children who are exposed to high levels of father involvement will score higher on measures of self-concept than the group of children with low father involvement or no father involvement.

Prediction 2: It was predicted that the group of children with low father involvement who have the experience of substitute father involvement (uncle, grandfather, coach, etc.) will score higher on self-concept measures than the group of children with low father involvement who do not have another significant male role model in their lives.

\section{Hypothesis 1:}

At both the multivariate and univariate levels, no significant main effect was found for father involvement. Thus, it is not possible to provide evidence for this hypothesis. One can look at the means for each self-concept variable to see how father involvement may influence one area of self-concept more than another. However, because no statistical 
significance was found, one cannot conclude with a reasonable amount of certainty that father involvement had a greater or lesser impact on any area of self-concept. Insert table 5 here

Prediction 1:

The results of the $2 \times 2$ MANOVA reveal that level of father involvement did not have a statistically significant main effect on child's self-concept on any of the six aspects of self-concept. However, the means for high father involvement were greater than those for low father involvement in each of the six aspects of self-concept. While not statistically significant, it is important to note that in every case, the means were in the direction of the author's prediction.

Insert table 6 here

prediction 2:

Results for the MANOVA interaction effect were not found to be statistically significant. However, on the univariate level two statistically significant interaction effects were found: The aspect of Affect Self-Concept was affected when the level of father involvement differed on level of substitute father involvement. The aspect of Social SelfConcept was also found to be affected when the levels of father involvement and substitute father involvement were different. However, because of the multiple ANOVAs performed, these results must be interpreted with caution.

Insert table 7 here

A $2 \times 2$ ANOVA was performed on total self-concept revealing borderline statistical significance $(p=.056)$. These results suggest that perhaps a child's total self- 
concept is affected when their level of father involvement is different from his or her level of substitute father involvement.

The MANOVA did yield a statistically significant main effect of substitute father involvement on the self-concept variables. On a univariate level substitute father involvement had a statistically significant effect on the aspects of Affect Self-Concept, Academic Self-Concept, and Family Self-Concept. Children who had relatively uninvolved fathers but experienced high involvement from a substitute father figure obtained significantly higher scores on the Academic, Affect, and Family self-concept subscales than those low father involvement children who experienced low levels of substitute father involvement.

Insert table 8 here

\section{Discussion}

The findings from this research suggest that the Parent Involvement Scale, the Father Involvement Scale, and the Substitute Father Involvement Scale each have utility in studying the involvement of significant adults in a child's life. This is significant because, at this time, well-standardized scales measuring these factors in the lives of school age children do not exist. Principal component analyses of these scales indicated excellent structure for each measure with each scale accounting for quite a bit of variance. Internal consistencies for each subscale were also very high.

Although the Parent Involvement, Father Involvement, and Substitute Father Involvement Scales show initial promise, future research is needed to gather construct validity including convergent and divergent validity studies. Test-retest reliability data with 
an interval between testing of at least six months would also need to be collected.

Because levels of adult involvement change throughout the child's development it would be necessary to collect normative data for different age groups. Included in this normative data should be participants from the cultural backgrounds represented in the most recent U.S. Census, as well as an effort to sample from both urban and rural areas from the different geographical regions of the U.S.

It would appear that each of the involvement scales could potentially provide a tremendous wealth of information to an infinite number of questions. The scales could be used to increase knowledge of the impact of involvement on child development and functioning, as well as a child's adjustment and performance in adulthood. Conversely, the involvement scales could be used to measure the correlation between a parent's involvement with their children and their own functioning both during their child's youth and later adulthood.

The reader will remember that the author posed the hypothesis that the degree of relationship between father involvement and specific areas of self-concept would differ. Because father involvement was not found to have a statistically significant effect on any of the self-concept variables it is not possible to say statistically, whether or not father involvement had a greater relationship with some areas of self-concept over others.

The author predicted that greater father involvement would be related to children obtaining higher scores on the MSCS. Again, because no statistically significant effects were found, it is not possible to conclude from the results of this study, that greater father involvement had a more significant impact on children's self-concept. 
No studies have been conducted investigating the father's influence on different dimensions of a child's self-concept or self-esteem. Therefore, it is not possible to compare these results with previous research examining these specific relationships. However, there have been studies which have looked at the relationship between father involvement and a measure of global self-esteem or overall adjustment.

The results from the present study run contrary to other studies which have employed a unidimensional dependent measure. Coopersmith (1967) studied several childhood experiences in his research on children's self-esteem. Among the family variables he examined, he found that a healthy level of self-esteem was related to having a father who expressed total acceptance and clearly and consistently defined limits for his children's behavior. In a more recent study, Field, et. al. (1995) investigated the relationships between intimacy and a variety of variables including self-esteem and depression. Studying 455 adolescents (ranging in age from 14-19 years), they found that students reporting greater intimacy with both their mother and father obtained higher selfesteem and lower depression scores. Amato (1986) investigated self-esteem in both elementary school children and adolescents. Both biologically intact families and stepfather families were included in the sample. Using the Piers-Harris Self-Concept Scale, he concluded that the father figures in both biologically intact and stepfather families had as much influence on self-esteem as mothers in both age groups.

Other studies have examined the relationship between father involvement and individual adjustment. Reuter and Biller (1973) studied the effects of paternal nurturance and availability during childhood on the personality adjustment of college males. They 
found that college males who experienced at least moderate paternal nurturance combined with at least moderate paternal availability, scored higher on the personality adjustment measures. Beaty (1995) also reported that father presence has a positive and significant impact on the adolescent's personal adjustment. Studying seventh and eighth grade boys, she found that father absent boys evidenced a poorer sense of masculinity as well as poorer interpersonal relationships than did father present boys. Biller and Bahm (1971) reported that boys who experienced father absence before five years old suffered the most. However, they found that when mothers encouraged aggressive behavior in these early father absent boys masculinity of self-concept was strengthened.

Some researchers have investigated the relationship between family makeup and children's self-esteem. Although not directly examining the father's influence on selfconcept, Parish (1991) investigated the variables of self-esteem and family type (biologically intact two parent, divorced nonremarried, and divorced remarried) in 648 children (ages 10 - 18). He found self-esteem to be significantly higher for those children from intact families compared to those from divorced remarried families. Interestingly, his results showed a family makeup by gender interaction effect. Self-esteem for boys was highest among those from divorced nonremarried families and lowest for those from divorced remarried families. In contrast, self-esteem for girls was highest for those from intact families while those from divorced nonremarried and divorced remarried families were comparable.

In contrast, Mensink and Sawatzky (1989) reported results which indicated that children's self-concept did not differ according to family type. In their study, children's 
ratings of their own self-concept were not significantly different whether these children came from single or two parent families. It is interesting to note that, in this study, it was found that both teachers and parents rated the self-concept of children from single parent families as lower than those from two parent families. The findings from their study raise the question of how adults subjectively perceive and subsequently treat children who do not live in two-parent, biologically intact families; families which are no longer the norm in American society.

Although the preponderance of research investigating the father's influence on self-concept has found a significant and positive correlation, one study was found that reported non-significant results. Tarantino and Loricchio (1989) examined the effects of father presence and father absence on self-concept in 88 ten year old boys and girls. Although early father absence seemed to negatively affect their later cognitive and linguistic abilities, no significant between group differences were found for self-concept.

Although the present study did not find a statistically significant effect for father involvement on the various dimensions of children's self-concept, substitute father involvement was found to have a significant relationship with a few self-concept domains (academic, affect, and family). It appears that, at least in this sample, other adult male figures strongly influenced the children's construct of self in academic, affect, and family spheres. Specifically, substitute father involvement was associated with a more positive self-concept in those children who experienced very little or no father involvement.

Results from studies examining the effects of significant others in a child's life on global self-esteem are mixed. Some researchers have found that the relative impact of the 
evaluations of significant others on adolescents' self-esteem decreases with age (McGuire,1984; Hirsch and Rapkin, 1987). However, Lackovic-Grgin and Dekovic (1990) found that this was true only for the male adolescent subjects in their study. They actually found the opposite pattern for girls. Significant others did seem to have an enormous impact on the adolescents' self-esteem. They found that the perceived evaluation of significant others for both boys and girls explained $60 \%$ of the variance in self-esteem. At the age of early adolescence children are continuing to move from a stage of dependency to one of autonomy. Therefore, it makes sense that at this point in their lives, they would place less importance on their parents' evaluations than those of significant others. Thus, parents would have less of an impact and significant others more of an influence on adolescents' self-esteem.

In the present study, substitute father involvement had more of an impact on the self-concepts of those children who experienced low father involvement than those who experienced high father involvement. This finding gives further support for social programs (e.g. Big Brothers), and athletic programs (e.g. the Police Athletic League or Midnight Basketball) which provide fatherless children with the nurturance and guidance of an adult male role model. The Seattle Mentorship Project (Payne, V.H., et. al., 1995) is an ongoing longitudinal project evaluating the effectiveness of social tutors on male children. Participants have a history of severe parental neglect and deprivation. The effectiveness of the mentors on these children are being evaluated by administering several psychological tests measuring a host of variables including self-concept and social skills. 
If significant effects on self-concept were found for substitute father involvement, then why was there no statistically significant effects found for father involvement? Several factors may have contributed to the absence of these positive results. The laws and regulations required for using minors as research participants, while necessary to protect the welfare of children, made it extremely difficult to accurately examine the hypothesis and predictions posed in this project. For example, for this research study, not only was it necessary to obtain the school's permission to administer the self-concept scale, but it was required that consent from parents and children be obtained as well. Moreover, it was required that an explicit description of the study including the variables being examined (i.e. the relationship between self-concept and parent-child relationships) be declared in the letter and consent forms. This undoubtedly caused many parents to decide not to participate. However, even more disturbing is the possibility that, because the participants were no longer blind to the variables being studied, they did not represent themselves accurately on the self-report data.

While the accuracy of self-report data has been called into question in the past, this may have been a particular problem in this research project. At least two situations may have contaminated the results. First, families in which fathers were not very involved may have overreported paternal involvement. Thus, some child participants may have been erroneously placed in the high father involvement group potentially driving down this group's self-concept scores. Second, in some families experiencing conflict there may have been a tendency to underreport father involvement. This may have been intensified by the fact that in most cases, the mother answered the Parent Involvement Questionnaire. 
In this situation, some children experiencing moderate to high father involvement would have been placed in the low father involvement group, potentially raising this group's scores on the MSCS.

The laws of doing research with children also contributed to a methodological problem in this study. It was extremely difficult to obtain a subject sample. First, the research needed to be approved by the school principal, then the schoolboard, then the supervisor of the school district. Although several attempts were made in many school districts, permission to conduct the research project was granted in just two schools. Once permission was granted, the response rate from parents was very poor. In one school, only $10 \%$ of parents agreed to participate. The response rate for the sample used in this research, while better, was still only $44 \%$. Because large sample statistics were needed to answer the questions in this study, this led to a difficulty in 1) getting enough subjects to run the appropriate statistics and 2) flexibility in dividing the groups. Eventually, enough subjects were obtained to conduct the necessary statistical analyses. However, the second issue was more of a problem, forcing the division of the two father involvement groups to be at the $50 \%$ percentile. Thus, it was not possible to divide groups into low, moderate, and high father involvement or compare those children with no father involvement to those with high father involvement.

Although no statistical significance was found for father involvement, the means for each of the self-concept variables were in the direction predicted by the author. Means were greatest for the high father involvement, low substitute father involvement group. The low father involvement, high substitute father involvement group had mean self- 
concept scores which approached those of the high father involvement group. The means for the low father involvement, low substitute father involvement group were the lowest. Interestingly, the means for the high father involvement, high substitute father involvement group were not greater than the high father involvement, low substitute father involvement group. Although not proposed in this study, this finding would seem to run contrary to a multiple involvement figure model (i.e. the more highly involved paternal figures in a child's life, the higher his or her self-esteem). It may be that a child will be relatively well adjusted if he receives an adequate degree of nurturance from a paternal figure (i.e. "good enough father").

The concept of nurturance is an interesting variable as it relates to a child's selfconcept. Theoretically, nurturance can be divided into the amount and quality of adult/child interactions in several facets of life. Usually when we think of these interactions, pleasant images are evoked of playtime, leisure, and parental caretaking. Only rarely are requirements of children to perform hard work, mandatory chores, or demanding school assignments placed into this category. However, these latter forms of nurturance express the message that the child is valued and competent. In his book, Greater Expectations (1996), William Damon writes, " Sparing children from demanding challenges...does them a disservice and imparts to children that they are incapable of accomplishing anything (p. 85)." Future research on the effects of adult involvement on children's self-concept may do well to examine the various levels of adult/child interactions and expectations with regard to work and discipline. 
Certainly, the results of this study warrant further investigation of the connection between adult involvement and its effects on different dimensions of a child's self-concept. The positive significant findings of substitute father involvement provide support for social programs to help fatherless children. In an age in which the current trend is to cut government sponsored programs, this would seem to be an especially significant finding. Potential directions for future work might include longitudinal designs to study the effects of a substitute father figure on self-concept throughout the child's development, as well as the impact on the child's academic, social, and/or career success. As mentioned above, the lack of significant findings for father involvement are not consistent with previous literature. However, no study has specifically examined the effects of father involvement on multiple domains of self-concept. Therefore, future work in this area is needed to test these results. It might be beneficial, for researchers who have the resources, to recruit a larger participant sample. With a greater number of subjects, researchers would be able to split the sample into three or more groups depending on level of father involvement. Finally, the scales developed for this study seem to have excellent component structure along with very high internal consistencies. While this initial data reveal excellent psychometric properties, future analyses of these scales should focus on establishing testretest reliability data, and convergent and divergent validity. 
Table 1

Eigenvalues for each item on parent involvement scale

$\begin{array}{llll}\text { Item \# } & \text { Eigenvalue } & \text { Item \# } & \text { Eigenvalue } \\ 1 & 7.512 & 14 & 0.446 \\ 2 & 3.387 & 15 & 0.393 \\ 3 & 2.339 & 16 & 0.362 \\ 4 & 1.701 & 17 & 0.325 \\ 5 & 1.345 & 18 & 0.285 \\ 6 & 1.137 & 19 & 0.277 \\ 7 & 1.046 & 20 & 0.256 \\ 8 & 0.929 & 21 & 0.209 \\ 9 & 0.823 & 22 & 0.168 \\ 10 & 0.759 & 23 & 0.144 \\ 11 & 0.627 & 34 & 0.135 \\ 12 & 0.599 & 25 & 0.132 \\ 13 & 0.572 & 26 & 0.092\end{array}$


Table 2

Component loadings and communality

$\begin{array}{llll}C 1 & C 2 & C 3 & h^{2} \\ -0.077 & -0.631 & 0.102 & 0.414 \\ 0.873 & 0.033 & 0.168 & 0.791 \\ -0.834 & -0.112 & -0.164 & 0.735 \\ 0.601 & 0.437 & -0.011 & 0.552 \\ 0.719 & 0.328 & 0.180 & 0.657 \\ -0.685 & -0.197 & -0.288 & 0.591 \\ -0.701 & -0.028 & -0.340 & 0.608 \\ 0.169 & 0.476 & -0.279 & 0.333 \\ 0.140 & 0.381 & -0.388 & 0.315 \\ -0.696 & 0.037 & -0.270 & 0.559 \\ \mathbf{0 . 4 9 3} & -0.168 & 0.053 & 0.274 \\ 0.277 & -0.472 & 0.063 & 0.303 \\ 0.075 & 0.044 & 0.138 & 0.027 \\ 0.552 & 0.030 & 0.037 & 0.307 \\ -0.020 & 0.771 & 0.129 & 0.611 \\ -0.891 & 0.062 & -0.023 & 0.798 \\ 0.036 & 0.772 & -0.005 & 0.597 \\ -0.864 & 0.044 & -0.138 & 0.767 \\ -0.816 & 0.013 & 0.003 & 0.666 \\ 0.028 & 0.624 & 0.063 & 0.394 \\ 0.130 & -0.120 & 0.582 & 0.370 \\ 0.105 & -0.138 & 0.714 & 0.540 \\ 0.193 & 0.109 & 0.628 & 0.444 \\ 0.024 & -0.080 & 0.771 & 0.601 \\ 0.150 & -0.102 & 0.685 & 0.502 \\ 0.175 & 0.081 & 0.665 & 0.479\end{array}$

prop. of variance accted for by each .261 .117 cum. prop. of variance .509

component

boldface indicates items loading $>.40$ on that component 
Table 3

Component loadings for father and substitute father involvement scale and communality

$\begin{array}{ccc}C 1 & C 2 & \mathrm{~h}^{2} \\ -0.887 & 0.128 & 0.803 \\ 0.847 & -0.136 & 0.736 \\ -0.752 & 0.121 & 0.580 \\ 0.741 & -0.089 & 0.557 \\ 0.735 & -0.292 & 0.625 \\ 0.722 & -0.262 & 0.590 \\ -0.447 & 0.076 & 0.206 \\ -0.564 & -0.079 & 0.324 \\ 0.867 & -0.075 & 0.757 \\ 0.857 & -0.151 & 0.757 \\ 0.814 & 0.010 & 0.663 \\ -0.105 & 0.805 & 0.659 \\ -0.030 & 0.887 & 0.788 \\ -0.161 & 0.808 & 0.679\end{array}$

prop. of variance accted for prop. of variance

cum. prop. of variance

0.456 accted for

0.167

0.623

boldface indicates items loading $>.40$ on that component 
Table 4

Internal consistency coefficients for the six subscales and total scale for MSCS

$\begin{array}{ll}\text { Scale } & \text { Standardized Alpha } \\ \text { Social } & 0.92 \\ \text { Competency } & 0.88 \\ \text { Affect } & 0.92 \\ \text { Academic } & 0.92 \\ \text { Family } & 0.97 \\ \text { Physical } & 0.91 \\ \text { Total } & 0.90\end{array}$


Table 5

Univariate F-tests with $(1,95)$ df for Father Involvement

\begin{tabular}{|c|c|c|c|c|c|c|}
\hline Variable & & SS & df & MS & $F$ & $p$ \\
\hline Social & & 20.521 & 1 & 20.521 & 0.18 & NS \\
\hline & Error & 10617.13 & 95 & 111.759 & & \\
\hline & Total & 10637.65 & 96 & 132.28 & & \\
\hline Competer & & 30.898 & 1 & 30.898 & 0.32 & NS \\
\hline & Error & 9104.46 & $\underline{95}$ & $\underline{95.836}$ & & \\
\hline & Total & 9135.358 & 96 & 126.734 & & \\
\hline Affect & & 402.247 & 1 & 402.247 & 3.37 & NS \\
\hline & Error & 11322.74 & $\underline{95}$ & 119.187 & & \\
\hline & Total & 11724.98 & 96 & 521.434 & & \\
\hline Academic & & 147.4 & 1 & 147.4 & 1.05 & NS \\
\hline & Error & 13382.38 & $\underline{95}$ & 140.867 & & \\
\hline & Total & 13529.78 & 96 & 288.267 & & \\
\hline Family & & 417.39 & 1 & 417.39 & 2.31 & NS \\
\hline & Error & 17146.26 & $\underline{95}$ & $\underline{180.487}$ & & \\
\hline & Total & 17563.65 & 96 & 597.877 & & \\
\hline Physical & & 102.62 & 1 & 102.62 & 0.84 & NS \\
\hline & Error & 11608.18 & $\underline{95}$ & $\underline{122.191}$ & & \\
\hline & Total & 11710.8 & 96 & 224.811 & & \\
\hline
\end{tabular}


Table 6

Cell Means for each group on self-concept domains

$\underline{\text { Social }}$

Father Involvement

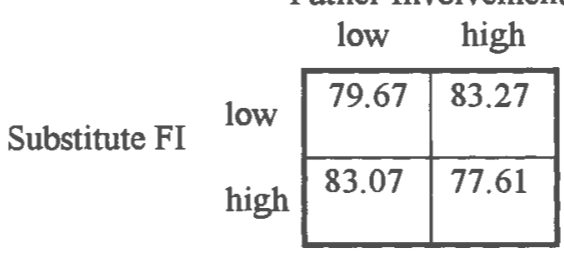

$\underline{\text { Affect }}$

Father Involvement low high

Substitute FI

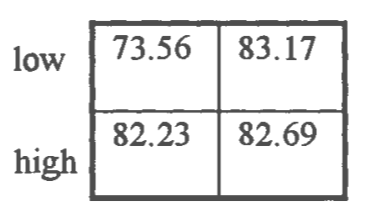

Family

Father Involvement

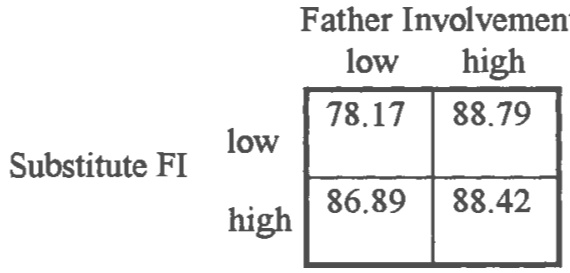

\section{Competence}

\begin{tabular}{ccc|c|}
\hline & \multicolumn{3}{c}{$\begin{array}{c}\text { Father Involvement } \\
\text { low }\end{array}$} \\
\cline { 3 - 4 } Substitute FI & low & 76.78 & 80.50 \\
\cline { 3 - 4 } & high & $\mathbf{8 1 . 7 6}$ & $\mathbf{8 0 . 3 0}$ \\
\hline & & &
\end{tabular}

\section{Academic}

\begin{tabular}{cc|c|c|} 
& \multicolumn{3}{c}{$\begin{array}{c}\text { Father Involvement } \\
\text { low }\end{array}$} \\
Substitute FI & low & 72.72 & 80.59 \\
\cline { 3 - 4 } & high & 77.92 & 80.35 \\
\hline
\end{tabular}

note - the number of participants in each group are as follows: low father involvement, low sub. father involvement $=18$; low father involvement, high sub. father involvement $=29$; high father involvement, low sub. father involvement $=26$; high father involvement, high sub. father involvement $=28$. 


\section{Table 7}

Interaction effect between father involvement and substitute father involvement on six aspects of self-concept

Univariate F-tests with $(1,95) \mathrm{df}$

\begin{tabular}{|c|c|c|c|c|c|c|}
\hline Variable & & SS & df & MS & $\mathrm{F}$ & $\mathrm{p}$ \\
\hline Social & & 491.214 & 1 & 491.214 & 4.4 & 0.039 \\
\hline & Error & 10617.13 & $\underline{95}$ & $\underline{111.759}$ & & \\
\hline & Total & 11108.35 & 96 & 602.973 & & \\
\hline Competen & & 160.29 & 1 & 160.29 & 1.67 & NS \\
\hline & Error & $\underline{9104.46}$ & $\underline{95}$ & $\underline{95.84}$ & & \\
\hline & Total & 9264.75 & 96 & 256.13 & & \\
\hline Affect & & 502.032 & 1 & 502.032 & 4.21 & 0.043 \\
\hline & Error & 11322.74 & $\underline{95}$ & $\underline{119.19}$ & & \\
\hline & Total & 11824.77 & 96 & 621.222 & & \\
\hline Academic & & 177.307 & 1 & 177.307 & 1.26 & NS \\
\hline & Error & 13382.38 & $\underline{95}$ & 140.87 & & \\
\hline & Total & 13559.69 & 96 & 318.177 & & \\
\hline Family & & 494.673 & 1 & 494.673 & 2.74 & NS \\
\hline & Error & $\underline{17146.26}$ & $\underline{95}$ & 180.487 & & \\
\hline & Total & 17640.93 & 96 & 675.16 & & \\
\hline Physical & & 227.894 & 1 & 227.894 & 1.87 & NS \\
\hline & Error & 11608.18 & $\underline{95}$ & $\underline{122.191}$ & & \\
\hline & Total & 11836.08 & 96 & 350.085 & & \\
\hline
\end{tabular}


Table 8

Univariate F-tests for Substitute father involvement with $(1,95) \mathrm{df}$

\begin{tabular}{|c|c|c|c|c|c|c|}
\hline Variable & & SS & df & MS & $\mathrm{F}$ & $p$ \\
\hline Social & & 30.363 & 1 & 30.363 & 0.27 & NS \\
\hline & Error & 10617.13 & $\underline{95}$ & 111.759 & & \\
\hline & Total & 10647.49 & 96 & 142.122 & & \\
\hline Competen & & 137.34 & 1 & 137.34 & 1.43 & NS \\
\hline & Error & $\underline{9104.46}$ & $\underline{95}$ & $\underline{95.84}$ & & \\
\hline & Total & 9241.8 & 96 & 233.18 & & \\
\hline Affect & & 608.37 & 1 & 608.37 & 5.1 & 0.026 \\
\hline & Error & 11322.74 & 95 & 119.19 & & \\
\hline & Total & 11931.11 & 96 & 727.56 & & \\
\hline Academic & & 633.821 & 1 & 633.821 & 4.5 & 0.037 \\
\hline & Error & 13382.38 & $\underline{95}$ & 140.87 & & \\
\hline & Total & 14016.2 & 96 & 774.691 & & \\
\hline Family & & 886.341 & 1 & 886.341 & 4.91 & 0.029 \\
\hline & Error & 17146.26 & $\underline{95}$ & $\underline{180.487}$ & & \\
\hline & Total & 18032.6 & 96 & 1066.828 & & \\
\hline Physical & & 233.614 & 1 & 233.614 & 1.91 & NS \\
\hline & Error & 11608.18 & $\underline{95}$ & $\underline{122.191}$ & & \\
\hline & Total & 11841.8 & 96 & 355.805 & & \\
\hline
\end{tabular}




\title{
Appendix A
}

\author{
Self-Concept Study \\ Assent Form to Act as a Research Participant \\ The University of Rhode Island \\ Department of Psychology \\ Kingston, RI 02881
}

I have been asked to take part in a research project studying parent-child relationships and how children think of themselves. This research project is being conducted by Jon Lopez Kimpton, a doctoral student in the clinical psychology department at the University of Rhode Island. It is being closely supervised by Dr. Henry Biller, Professor of Psychology at the University of Rhode Island. If I have any questions regarding the present study, now or at any time in the future, I should feel free to contact Jon Lopez Kimpton, at 1-800/430-9570.

My part in this study is strictly confidential. None of the information will identify me by name, all records will be given a coded identification number, and only Jon Lopez Kimpton will retain a list, in a locked file cabinet, equating name and identification number.

If I decide to take part in this study, here is what will happen: I will sign this assent form and answer questions on a self-concept survey. On this survey I will be asked to rank statements involving how I feel about myself in different areas of life. This is a paper and pencil survey and will be given in the classroom. It will take approximately 20-30 minutes to complete. If I feel uncomfortable answering these questions, I can quit at anytime. In addition, Jon Lopez Kimpton will be available for consultation. If I do not agree or my parents have not agreed to participate, then I will be given alternative activities to do during the administration of the self-concept survey.

Although there will be no direct benefit to me for taking part in this study, it is hoped that the research will provide useful information about the ways in which sixth and seventh grade students perceive themselves. This knowledge will benefit parents, teachers and counselors in the education and guidance of students, and contribute guidelines for the development of specific programs.

The decision whether or not to take part in this study is up to me. I do not have to participate. If I decide to take part in the study, I may stop at any time by simply informing Jon Lopez Kimpton of my decision. There will be no negative consequences to me whatsoever. Participation in this research project will in no way affect my involvement in school activities.

If I am not satisfied with the way this study is performed, I may discuss my complaints with Jon Lopez Kimpton at 1-800/430-9570. In addition, I may contact the office of the Vice Provost for Research, 70 Lower College Road, University of Rhode Island, Kingston, Rhode Island, (401) 792-2653. 
I have read this form, understand what my participation involves, and all my questions have been answered. My signature on this form indicates that I'm willing to take part. I know that I don't have to take part and that I can stop at any time if I decide to do so.

child's signature

typed/printed name

date

date of birth signature of researcher

typed/printed name

date 


\title{
Appendix B
}

\author{
Self-Concept Study \\ Consent Form to Act as a Research Participant \\ The University of Rhode Island \\ Department of Psychology \\ Kingston, RI 02881
}

I have been asked to take part in a research project studying parent-child relationships and how children think of themselves. This research project is being conducted by Jon Lopez Kimpton, a doctoral student in the clinical psychology department at the University of Rhode Island. It is being closely supervised by Dr. Henry Biller, Professor of Psychology at the University of Rhode Island. If I have any questions regarding the present study, now or at any time in the future, I should feel free to contact Jon Lopez Kimpton, at 1-800/430-9570.

My part and my child's part in this study is strictly confidential. None of the information will identify me by name, all records will be given a coded identification number, and only Jon Lopez Kimpton will retain a list, in a locked file cabinet, equating name and identification number.

If I decide to take part in this study, here is what will happen: I will sign the consent form, fill out the enclosed parenting survey and mail them to Jon Lopez Kimpton. A few of the questions on the parent questionnaire may seem to be somewhat personal. However, this information is essential in order to obtain a clear picture of parent - child interactions.

If I decide to participate and my child decides to participate, then $s /$ he, will sign an assent form to fill out a self-concept survey. On this survey children are asked to rank statements involving how they feel about themselves in different areas of their lives. This is a paper and pencil survey and will be given in the classroom. It will take approximately 20-30 minutes to complete. In the event that any discomfort is experienced, Jon Lopez Kimpton will be available for consultation. Those children who have not received consent from their parents and/or themselves not agreed to participate will be given alternative activities to do during the administration of the self-concept survey.

Although there will be no direct benefit to me for taking part in this study, it is hoped that the research will provide useful information about parent - child relationships and the ways in which a child perceives him/herself. This knowledge will benefit parents, teachers and counselors in the education and guidance of children, and contribute guidelines for the development of specific programs. As an outgrowth of this research, therefore, Jon Lopez Kimpton hopes to make positive recommendations for these programs and guidelines so as to assist the school in the accomplishment of their educational goals.

The decision whether or not to take part in this study is up to me. I do not have to participate. If I decide to take part in the study, I may stop at any time by simply informing Jon Lopez Kimpton of my decision. There will be no negative consequences to me or my child. 
If my child decides to participate, s/he may also stop at any time. Participation in this research project in no way affects my child's involvement in school activities.

If I am not satisfied with the way this study is performed, I may discuss my complaints with Jon Lopez Kimpton at 1-800/430-9570. In addition, I may contact the office of the Vice Provost for Research, 70 Lower College Road, University of Rhode Island, Kingston, Rhode Island, (401) 792-2653.

I have read this consent form and all my questions have been answered. I have discussed the project with my child. My signature on this form means that I understand the information, agree to participate, and allow my child to participate in this study.

signature of participant

typed/printed name

date

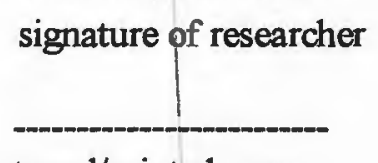

typed/printed name

date 


\section{Appendix C}

\section{Parent Questionnaire}

Please answer the following questions. Whenever possible they should be answered by the child's mother and father. When one spouse is not available, the other can fill out the questionnaire alone. These questions pertain to your seventh grade child only. If you do not wish to participate in this research project please sign your name at the end of this questionnaire.

Name of person answering questionnaire

Relationship to seventh grade child

What is the makeup of your household? (children, yourself, spouse, extended family members, friends, etc.)

current marital status: married divorced/separated(spouse lives outside home) widow(ed) remarried

If separated/divorced or widow(ed) for how many years?

If remarried for how many years?

If child's father has been absent from home, for how long has he been absent?

Mother's occupation:

Father's occupation:

How involved are you (is your spouse)

$\begin{array}{ccccccc}\text { in caring for your children? } & \text { mother } & 1 & 2 & 3 & 4 & 5 \\ \text { father } & 1 & 2 & 3 & 4 & 5\end{array}$

Not counting the hours your youngster is in a school or center, with a sitter, or asleep for the night, what percentage of the remaining time is the father the child's prime caregiver? \% What percentage is the mother the prime caregiver? \% (By prime caregiver is meant the person who must be available to attend to the child's needs.)

Who in your family generally makes decisions about the following and how frequently?

When child should be disciplined

1 - father always 2 - father more than mother 3 - father and mother equally 4 - mother more than father 5 - mother always

When child is old enough to try new things 1 - mother always 2 - mother more than father 3 - father and mother equally 4 - father more than mother 5 - father always 
How often are you or your spouse:

away from home on weekends

\begin{tabular}{|c|c|c|}
\hline & \\
\hline \multicolumn{3}{|c|}{$\begin{array}{ccc} & \text { all the time } & \text { frequently } \\
\text { father } & 0 & 1\end{array}$} \\
\hline mother & 0 & 1 \\
\hline
\end{tabular}

sometimes infrequently never

out in the evening at least

2 nights a week

mother 0

father 0

2

34

$\begin{array}{lll}2 & 3 & 4\end{array}$

have breakfast during the week with children

$\begin{array}{clll}\text { father } & 0 & 1 & 2 \\ \text { mother } & 0 & 1 & 2\end{array}$

3

34

home afternoons when children come home from school

mother 0

father 0

3

34

1. How many hours does child spend playing or talking with mother on an average day?
0 hours
$1 / 2$ hour 1 hour
2 hours
3 or more hours

2. How many hours does child spend playing or talking with father on an average day?
0 hours
$1 / 2$ hour
1 hour
2 hours
3 or more hours

3. On days during the weekend and in the summer, how much time does child spend with mother?
$0 \mathrm{hrs}$
$1 / 2 \mathrm{hr}$
$1 \mathrm{hr}$
2 hrs
$3 \mathrm{hrs}$
4 hrs
$5 \mathrm{hrs}$
6 or more hrs

4. On days during the weekend and in the summer, how much time does child spend with father?

\begin{tabular}{lllllll|l}
$0 \mathrm{hrs}$ & $1 / 2 \mathrm{hr}$ & $1 \mathrm{hr}$ & $2 \mathrm{hrs}$ & $3 \mathrm{hrs}$ & $4 \mathrm{hrs}$ & $5 \mathrm{hrs}$ & 6 or more hrs
\end{tabular} 
5. How often does child go on outings with father (such as swimming, ball games, bowling, movie, etc.)?

Never Less than once a month Once or twice a month Once a week Two or more times a week

6. How often does child go on outings with mother (such as swimming, ball games, bowling, movie, etc.)?

Never Less than once a month Once or twice a month Once a week

Two or more times a week

7. Does mother or father work outside the home on Saturday or Sunday?

Mother Yes No

Father Yes No

Are there other male adult figures who either live in the home or nearby that spend a significant amount of time with child (for example, uncle, grandfather, stepfather, teacher, coach, friend's father, neighbor, "big brother", etc.)?

Please specify this relationship:

Is there another male adult figure in the home? Yes No If yes, when did he begin living in the home?

Are there other female adult figures who either live in the home or nearby that spend a significant amount of time with child (for example, aunt, grandmother, stepmother, teacher, coach, friend's mother, neighbor, "big sister", etc.)?

Please specify this relationship:

Is there another female adult figure in the home? Yes No If yes, when did she begin living in the home?

1. How many hours does child spend playing or talking with other women on an average day?

0 hours $\quad 1 / 2$ hour $\quad 1$ hour $\quad 2$ hours 3 or more hours 
2. How many hours does child spend playing or talking with other men on an average day?
0 hours
$1 / 2$ hour 1 hour
2 hours
3 or more hours

3. On days during the weekend and in the summer, how much time does child spend with other women?

$0 \mathrm{hrs} \quad 1 / 2 \mathrm{hr} \quad 1 \mathrm{hr} \quad 2 \mathrm{hrs} \quad 3 \mathrm{hrs} \quad 4 \mathrm{hrs} \quad 5 \mathrm{hrs} \quad 6 \mathrm{or}$ more hrs

4. On days during the weekend and in the summer, how much time does child spend with other men?

$0 \mathrm{hrs} \quad 1 / 2 \mathrm{hr} \quad 1 \mathrm{hr} \quad 2 \mathrm{hrs} \quad 3 \mathrm{hrs} \quad 4 \mathrm{hrs} \quad 5 \mathrm{hrs} \quad 6$ or more hrs

5. How often does child go on outings with other men (such as swimming, ball games, bowling, movie, etc.)?

Never Less than once a month Once or twice a month Once a week Two or more times a week

6. How often does child go on outings with other women (such as swimming, ball games, bowling, movie, etc.)?

Never Less than once a month Once or twice a month Once a week

Two or more times a week

We have found in our research that parental input is extremely important. We invite you to evaluate this questionnaire and tell us of any improvements you think could be made to make it better. In the space below please describe what you liked about the questionnaire as well as what you did not like. 


\section{Bibliography}

Adler, A. (1927) The Practice and Theory of Individual Psychology, Harcourt, New York.

Amato, P. (1986), Father involvement and the self-concept of children and adolescents. Australian Journal of Sex, Marriage, and Family, 7, 6-16.

Beaty, L.A. (1995) Effects of paternal absence on male adolescents' peer relations and self-image. Adolescence, 30, 873-880.

Biller, H.B. (1971) Father, Child, and Sex Role, Lexington, MA: Lexington Books.

Biller, H.B. (1974) Paternal Deprivation: Family, School, Sexuality, and Society, Lexington, MA: Lexington Books.

Biller, H.B. (1993) Fathers and Families: Paternal Factors in Child|Development, Westport, CT: Auburn House.

Biller, H.B. and Solomon, R.S. (1986) Child Maltreatment and Paternal Deprivation: A Manifesto for Research, Prevention, and Treatment, Lexington, MA: Lexington Books.

Blanchard, R.W. and Biller, H.B. (1971) Father availability and academic performance among third grade boys. Developmental Psychology, 4, 301-305.

Bracken, B.A. (1992) The Multidimensional Self Concept Scale. Austin, TX: Pro Ed.

Cooley, C.H. (1902) Human Nature and the Social Order, New York: Scribners.

Coopersmith, S. (1967) The Antecedents of Self-Esteem, San Francisco: W.H. Freeman and co. 
Corsini, R. (1984) The Encyclopedia of Psychology, New York: Wylie.

Field, T.; Lang, C.; Yando, R.; and Bendell, D. (1995) Adolescents'| intimacy with parents and friends. Adolescence, 30, 133-140.

Goodenough, E.W. (1957) Interest in persons as an aspect of sex differences in the early years. Genetic Psychology Monographs, 55, 287-323.

Harter, S. (1985) Manual for the Self Perception Profile for Children, Denver: University of Denver.

Harter, S. (1986) Processes underlying the construction, maintenance, and enhancement of the self-concept in children. In J. Suls and A. Greenwald (Eds.), Psychological Perspectives on the Self Vol. 3. Hillsdale, NJ: Lawrence Erlbaum Associates.

Harter, S. (1986) Manual: Social Support Scale for Children. University of Denver, Denver.

Harter, S. (1987) The determinants and functional role of self-worth. In N. Eisenberg (Ed.), Contemporary Topics in Developmental Psychology, New York: Wiley.

Harter, S. (1988) The construction and conservation of the self. James and Cooley revisited. In D. K. Lapsley and F. C. Bower (Eds.) Self, Ego, and Identity: Integrative Approaches. New York: Springer-Verlag.

Hirsch, B.J. and Rapkin, B.D. (1987) The transition to junior high school: longitudinal study of self-esteem, psychological symptomatology, school life and social support. Child Development, 58, 1235-1243.

James, W. (1890) Principles of Psychology, New York: Holt. 
Lackovic-Grgin, K. and Dekovic, M. (1990) The contribution of significant others to adolescents' self-esteem. Adolescence, 100, 839-846.

Lamb, M.E. (1986) The Father's Role: Applied Perspectives, New York: John Wiley and Sons, Inc.

McGuire, W.J. (1984) Search for the self: Going beyond self-esteem and the reactive self. In R.A. Zucker, J. A. Aronoff, and A.I. Rabin (Eds.), Personality and prediction of behavior. New York: Academic Press.

Mensink, D.L. and Sawatzky, D.D. (1988) The impact of family form on perceptions of children's functioning. Alberta Journal of Educational Research, 35, 237-254. Merenda, P. (1984) Common Errors of Omission and Commission in Pre-publication Manuscripts, Theses and Dissertations. Unpublished manuscript, University of Rhode Island.

Parish, T.S. (1991) Ratings of self and parents by youth: Are they affected by family status, gender, and birth order? Adolescence, 26, 105-112.

Payne, V.H.; Cathcart, D.J.; Pecora, P.J. (1995) The Seattle Mentorship Project:

Evaluating the effectiveness of social tutors. Community Alternatives International Journal of Family Care, 7, 1-21.

Piers, E.V. (1984) Piers-Harris Children's Self-Concept Scale: Revilsed Manual, Los Angeles: Western Psychological Services.

Radin, N. (1982). Primary caregiving and rolesharing fathers of preschoolers. In M. E. Lamb (Ed.) Nontraditional families: Parenting and child development. Hillsdale, NJ: Erlbaum. 
Radin, N. (1986). The influence of fathers on their sons and daughters. Social Work in Education, 77 - 91.

Radin, N. (1985) Validity and Reliability of the Paternal Involvement in Child Care Index. University of Michigan

Radin, N. (1985) Paternal Involvement in Child Care Index. University of Michigan

Radin, N., and Russel, G. (1983). Increased father participation and child development outcomes. In M.E. Lamb and A. Sagi (Eds.) Fatherhood and family policy. Hillsdale, NJ: Erlbaum.

Rogers, C.R. (1951) Client-Centered Therapy: Its Current Practice, Implications, and Theory, Boston: Houghton Mifflin.

Rosenberg, M. (1965) Society and the Adolescent Self-Image, Princeton: Princeton University Press.

Rosenberg, M. (1979) Conceiving the Self, New York: Basic Books.

Snarey, John (1993) How Fathers Care for the Next Generation, Cambridge: Harvard University Press.

Tabachnick, B.G. and Fidell, L.S. (1989) Using Multivariate Statistics, 2nd ed. New York: Harper Collins Publishers.

Tarantino, S.J. and Loricchio, D.F. (1989) Field dependence, language ability, and selfconcept as a function of fathers' absence. Perceptual and Motor Skills, 69, 431434.

Wells, L.W. and Marwell, G. (1976) Self-Concept: Its Conceptualization and Measurement, Beverly Hills, CA: Sage. 
Wylie, R.C. (1989) Measures of Self-Concept, Lincoln: University of Nebraska Press.

Zwick, W.R and Velicer, W.F. (1986) Comparison of five rules for determining the number of components to retain. Psychological Bulletin, 99, 432-442. 